九州大学学術情報リポジトリ

Kyushu University Institutional Repository

\title{
On Image Database File TOBIKOBACHI Based on the Japanese Encyrtid Wasps
}

Tadauchi, 0samu

Inoue, Hitoshi

Higashiura, Yoshimitsu

https://doi.org/10.5109/2673

出版情報 : ESAKIA. 43，pp.51-56，2003-03-31. Entomological Laboratory，Faculty of Agriculture， Kyushu University

バージョン :

権利関係 : 


\title{
On Image Database File TOBIKOBACHI Based on the Japanese Encyrtid Wasps ${ }^{1), 2)}$
}

\author{
Osamu TADAUCHI \\ Entomological Laboratory, Faculty of Agriculture, Kyushu University, \\ Fukuoka, 812-8581 Japan \\ Hitoshi INOUE \\ Computing and Communications Center, Kyushu University, \\ Fukuoka, 812-8581 Japan \\ and

\section{Yoshimitsu HIGASHIURA} \\ Yamaguchi Prefectural Ohshima Citrus Experimernt Station, Adaka, Higashiagenosho, \\ Tachibana-cho, Oshima-gun, Yamaguchi Pref., 742-2805 Japan
}

\begin{abstract}
An image database file TOBIKOBACHI based on the Japanese Encyrtid wasp collection of Dr. T. Tachikawa is reconstructed and open to the public via the Internet. Each record is composed of 16 items as follows: scientific names (family, genus and species), Japanese name, distribution data, type locality, type depository, source of the original description, synonymy, flying season, hosts, parasites, references, notes and images. The images include various parts of the body, such as the general habitus, head, antenna, mandible, scutellum, wings, stigmal vein and genitalia. A home page of the TOBIKOBACHI is presented. It is administered by a SIGMA management system.
\end{abstract}

Key words: bioinformatics, entomology database, Japanese Encyrtid wasps, images, TOBIKOBACHI, SIGMA, Internet.

1) Contribution from the Entomological Laboratory, Faculty of Agriculture, Kyushu University, Fukuoka (Ser. 5, No. 88).

2) This work was partly supported by a Grant-in-Aid for Scientific Research (No. (B)(2) 09490028) from the Ministry of Education, Science, Sports and Culture, Japan and Japan Society for the Promotion of Science (Head investigator: O. Tadauchi). 
We have constructed species information database on Japanese, East Asian and Pacific insects, KONCHU (about 130,000 records at present) which includes five main files, KONCHUR, HANABACHI, MOKUROKU, DJI and ELKUType (Tadauchi et al., 2002). It is available to the public via the Internet. In 1991 Tadauchi and Higashiura constructed an image database file TOBIKOBACHI (= Encyrtid wasp in Japanese) (first version), which was based on Encyrtid wasp collection of Prof. Emeritus Tetsusaburo Tachikawa of Ehime University presented to Entomological Laboratory, Kyushu University (Tadauchi \& Higashiura, 1996). However the images in the database of the first version were stored in a metallic optical disk (CRV disc) in a Laser videodisc recording system (Sony, Inc.) and the file was on an off line network. Although the TOBIKOBACHI file was our first image database, it was not available to the public and our second database file HANABACHI based on the Japanese bees was opened via the Internet earlier (Tadauchi et al., 2001). In the present work we took all the images in the old TOBIKOBACHI file from the CRV disc in a PC computer and reconstructed a new image database file TOBIKOBACHI (second version) with various literal data.

The TOBIKOBACHI is a special file including detailed data of the Japanese Encyrtid wasps such as taxonomy, biology and distribution with various images of the body. Each record is composed of 16 items with the following tags:

1. (FTAX) family (scientific name, including subfamily name)

2. (GTAX) genus (scientific name, including subgenus name)

3. (STAX) species (scientific name, including subspecies name)

4. (JTAX) Japanese name

5. (DST) distribution (Japan inland; overseas)

6. (TYPE) type

7. (TYPEL) type locality

8. (TYPED) depository of the type

9. (DESC) source of the original description

10. (SYN) synonymy

11. (FLY) flying season

12. (HOST) hosts

13. (PAR) parasites

14. (REF) references

15. (NOTE) notes

16. (IMG) images 


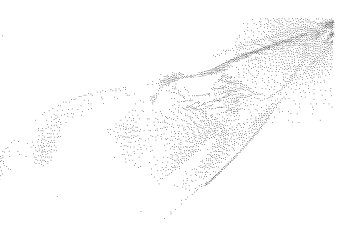

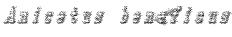

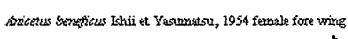

Welcome to Image Database TOBKOBACHI Based on the Encyrtid Wasp

Colletion of Dr. T. Tachikawa!

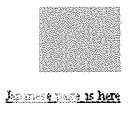

I.

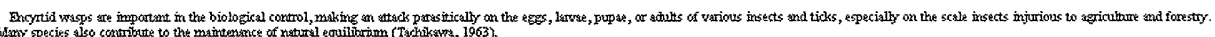

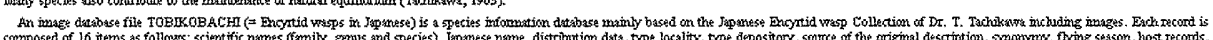

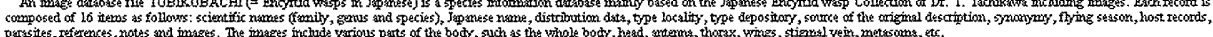

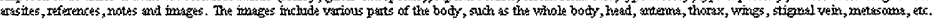

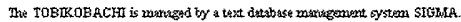

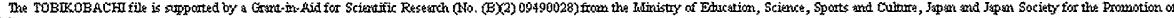
sience.

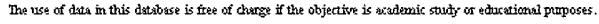

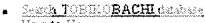

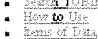

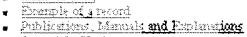

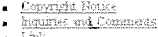

72y tems of Data

Dita and Togs are the Following 16 ittems.

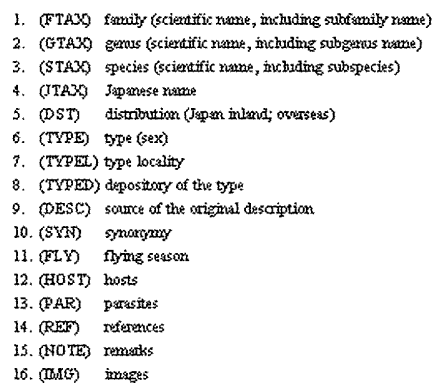

Wximple of a record

\begin{tabular}{|c|c|}
\hline FTAX) & 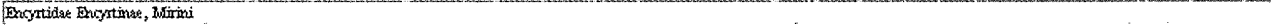 \\
\hline (GTAX) & sicicetss \\
\hline (STAB) & 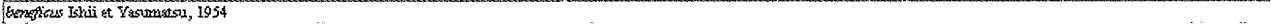 \\
\hline (JTAX) & Bobli- aksyadon-tobiksobichi \\
\hline (DST) & 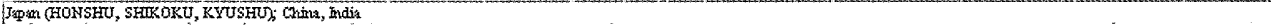 \\
\hline (TYPE) & Fenale \\
\hline \multicolumn{2}{|l|}{ (TYpसI) } \\
\hline \multicolumn{2}{|l|}{ (TYREL) } \\
\hline OESC) & 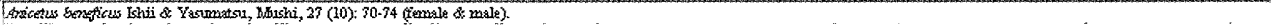 \\
\hline$(3 \times N)$ & 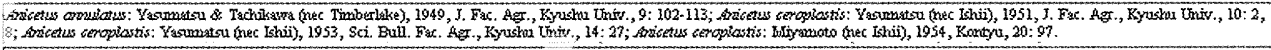 \\
\hline FLD & 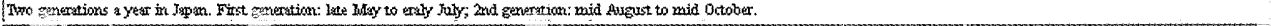 \\
\hline$($ HOST) & 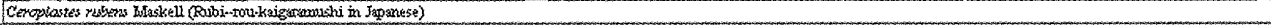 \\
\hline \multicolumn{2}{|l|}{ (PAR) } \\
\hline (REA) & 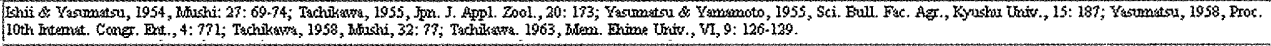 \\
\hline (NOTE) & 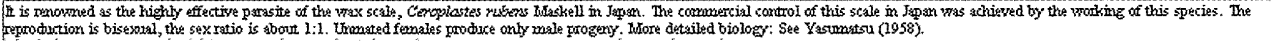 \\
\hline
\end{tabular}

Fig. 1. Home page of the image database file TOBIKOBACHI based on the Japanese Encyrtid wasps in English version. A Japanese version is also available. 


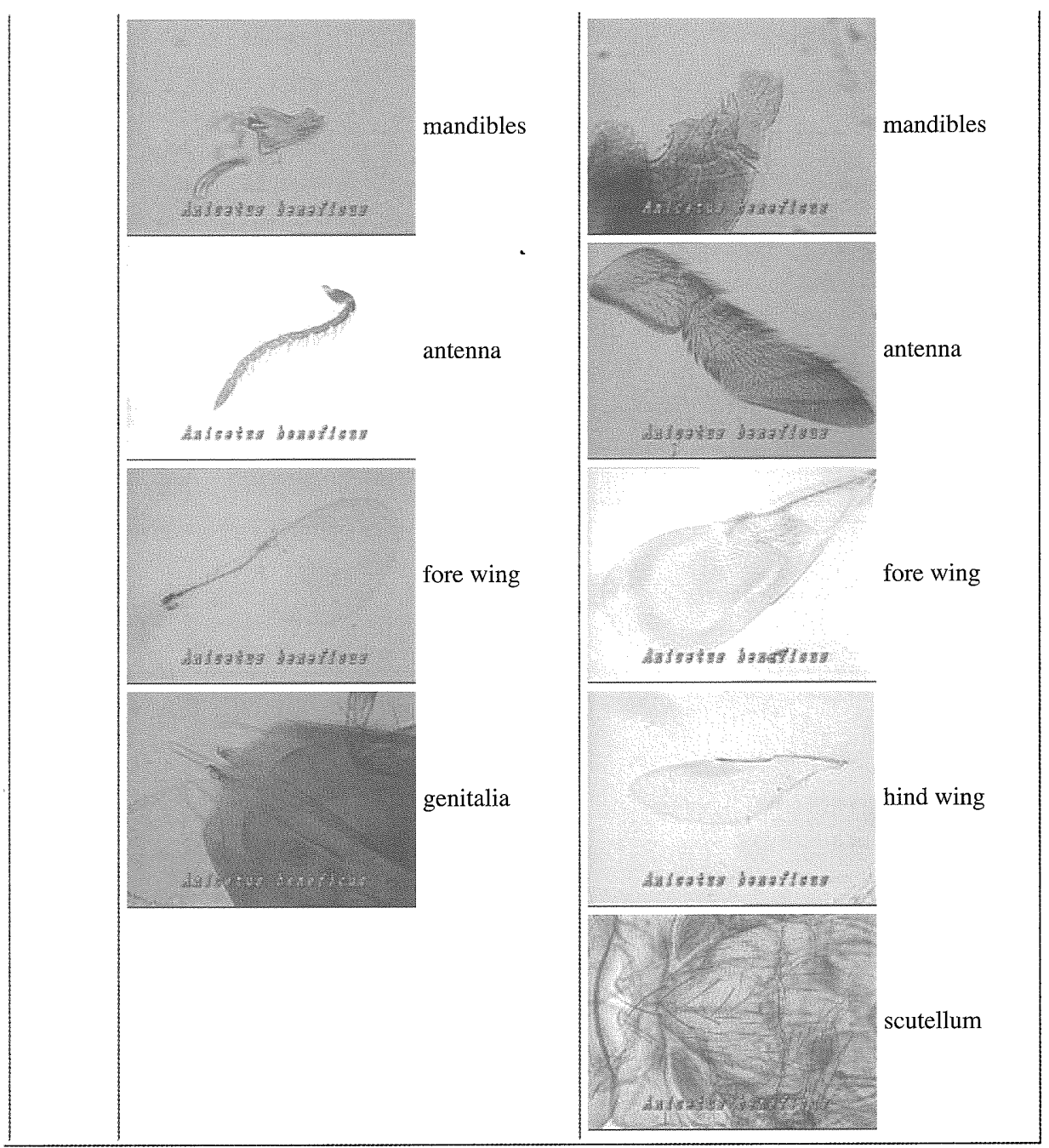

Publications, Manuals and Explanations

- Tadauchi, O. \& Y. Higashiura, 1996. Image database file TOBIKOBACHI, in a taxon-based entomology database KONCHU, using metallic optical disk (Hymenoptera, Encyrtidae). Jap. J. Entomol., 64: 613-614.

\section{Copyright Notice}

Entomology Database Project Group (Head: Osamu Tadauchi, Editor: Yoshimitsu Higashiura, System administrator: Hitoshi Inoue) holds the copyright on the entomology database TOBIKOBACHI.

Fig. 2. An Example of the images, Anicetus beneficus Ishii et Yasumatsu, in the image database TOBIKOBACHI. 
Encyrtid wasps are important in the biological control, making an attack parasitically on the eggs, larvae, pupae, or adults of various insects and ticks, especially on the scale insects injurious to agriculture and forestry (Tachikawa, 1963). The image database TOBIKOBACHI will be helpful for applied entomologists and biologists as well as taxonomists to get species information with images on the Japanese Encyrtid wasps. The images include various parts of the body, such as the general habitus, head, antenna, mandible, scutellum, wings, stigmal vein and genitalia. It is written mainly in English with Japanese and is administered by a SIGMA management system working at a workstation in the Entomological Laboratory, Kyushu University.

A user can access to the database file by visiting the following URL: http:// konchudb.agr.agr.kyushu-u.ac.jp/tobikobachi/. The home page of the TOBIKOBACHI is presented in Figs. 1-3. The operation of the SIGMA system is explained in Arikawa et al. $(1987,1988)$.

\section{Acknowledgments}

We are indebted to Prof. Emeritus T. Tachikawa of Ehime University for his provide of valuable collection. We are also grateful to Prof. J. Yukawa and Mr. R. Murao of Kyushu University for their various help and to Mr. T. Ohka of AVOC, Inc. in Fukuoka City for his preparing of a Laser videodisc recording system, which was useful for taking images from old CRV disc.

\section{References}

Arikawa, S. et al., 1987. A text database management system SIGMA, Version 2. Koho, Computer Center Kyushu Univ., 20: 517-581. (In Japanese.)

Arikawa, S. et al., 1988. SIGMA: A text database management system. RIFIS Techn. Rep. Res. Inst. Fundam. Inform. Sci., Kyushu Univ., CS-3: 1-16.

Tachikawa,T., 1996. Revisional studies on the Encyrtidae of Japan (Hymenoptera: Chalcidoidea). Mem.Ehime Univ., Sect VI, 9: 1-264.

Tadauchi, O. \& Y. Higashiura, 1996. Image database file TOBIKOBACHI, in a taxon-based entomology database KONCHU, using metallic optical disk (Hymenoptera, Encyrtidae). Jap. J. Entomol., 64: 613-614.

Tadauchi, O., A. Dawut \& H. Inoue, 2001. On image database file HANABACHI based on the Japanese bees. Esakia, (41): 149-154. 
Tadauchi, O., S. Kamitani, H. Inoue \& A. Dawut, 2002. On database file ELKUType based on the type collection preserved in the Entomological Laboratory, Kyushu University. Esakia, (42): 41-46. 